\title{
An evaluation of the efficiency of beekeeping enterprises in Turkey: The case of Mersin City
}

\author{
Osman UYSAL \\ Malatya Turgut Ozal University, Faculty of Agriculture, Department of Agricultural Economics, Malatya, Turkey \\ ORCID: 0000-0002-9010-2988

Corresponding author: osman.uysal@ozal.edu.tr
Received date: 21.01.2021 - Accepted date: 01.07.2021

\begin{abstract}
Beekeeping contributes significantly to both beekeeping enterprises and the country's economy, as it provides jobs, income, and nutrition for the rural population of developing countries. Mersin City is an essential region for beekeeping, both in terms of honey production and migratory beekeeping in Turkey. In this study, the efficiency of beekeeping enterprises was revealed, and the factors causing inefficiency were examined. The efficiency measure of enterprises was determined using data envelopment analysis (DEA). According to the findings obtained, beekeeping enterprises' technical efficiency, allocation efficiency, and economic efficiency were calculated as $0.89,0.84$, and 0.81 , respectively. The economic efficiency score showed that inefficient enterprises could effectively reduce their production costs by $19 \%$. When the factors causing inefficiency are examined, it is revealed that income per hive, subsidy rate, and credit use have adverse effects on efficiency, education level, experience, number of honey frames used per hive, and migratory beekeeping effects. According to the results, it is thought that increasing education and extension activities, improving marketing opportunities, legal regulations in using agricultural credits, and extending consultancy services can also help to increase economic efficiency in the research field.
\end{abstract}

Keywords: Beekeeping, data envelopment analysis, efficiency, honey production, Tobit model.

\section{Türkiye'deki arıcılık işletmelerinin etkinliğinin değerlendirilmesi: Mersin ili örneği}

Özet: Arıcılık, gelişmekte olan ülkelerin kırsal nüfusu için iş, gelir ve beslenme olanağı sağlaması nedeniyle hem işletmelere hem de ülke ekonomisine önemli katkılar sağlamaktadır. Mersin, Türkiye'de hem bal üretimi hem de gezginci arıcılık açısından önemli bir il konumundadır. Bu çalışmada arıcılık işletmelerinin etkinliği ortaya konulmuş, ayrıca etkinsizliğe neden olan faktörler incelenmiştir. İşletmelerin etkinlik ölçümü veri zarflama analizi (VZA) kullanılarak belirlenmiştir. Elde edilen bulgulara göre, arıcılık işletmelerinin teknik etkinliği 0,89 , tahsis etkinliği 0,84 ve ekonomik etkinliği ise 0,81 olarak hesaplanmıştır. Ekonomik etkinlik skoru dikkate alındığında, etkin olmayan işletmelerin üretim maliyetlerini \%19 oranında azaltarak etkin hale gelebileceğini göstermektedir. Etkinsizliğe neden olan faktörler incelendiğinde ise kovan başına gelir, sübvansiyon oranı ve kredi kullanımının etkinlik üzerinde negatif, eğitim düzeyi, deneyim, kovan başına kullanılan bal çerçevesi sayısı ve gezginci arıcılığın ise pozitif etkileri olduğu ortaya çıkmaktadır. Elde edilen sonuçlara göre, eğitim ve yayım faaliyetlerinin artırılması, pazarlama olanaklarını geliştirilmesi tarımsal kredi kullanımında yasal düzenlemeler ve danışmanlık hizmetlerinin yaygınlaştırılması da araştırma alanında ekonomik etkinliğin artırılmasına yardımcı olabileceği düşünülmektedir.

Anahtar sözcükler: Arıcıllk, bal üretimi, etkinlik, Tobit model, veri zarflama analizi.

\section{Introduction}

Beekeeping is a common agricultural activity with significant differences in its economic structure, contribution to rural development, and technical features. In recent years, migratory beekeeping activities have increased, and bee products have diversified. Therefore, productivity and quality features have come to the forefront in Turkey.
Turkey contains $20 \%$ of the world's bee races $(5,7)$. Turkey has $75 \%$ of the world's honeyed plant flora, and it has a tremendous opportunity for beekeeping in terms of rich flora, habitats, colony life, and genetic diversity in the bee population $(16,24,25,27)$. This potential can be activated by studies that will help beekeepers choose suitable bees for honey and other bee product production and suitable feeding places. Thus, it is possible to increase the revenue of beekeepers in Turkey $(14,20)$. 
Mersin City is one of the most suitable regions, mainly for migratory beekeeping in Turkey (17), and ranks $7^{\text {th }}$ with 2270 beekeeping enterprises in Turkey. The honey production accounts for $2.15 \%$ of the total production amount with 2352 tones and $1.69 \%$ of the production amount with 67 tones in wax production (28).

There are several benefits of beekeeping, i.e., extra profits over a shorter period, fulfilling the families' daily needs, pollination, and the productive use of family labor (18), and biodiversity conservation (4). Furthermore, honey production is unavoidable for producing healthy and intelligent future generations as well as developing rural development (3). However, the Turkish beekeeping sector has faced technical and economic challenges, such as low hive productivity, bee diseases, pests, failure to increase export potential, difficulties in marketing, an inadequate degree of industrial organization, and unexpected migratory beekeeping. In addition to the sector's challenges, competition in the globalizing environment has become a vital aspect that the Turkish apiculture sector needs to recognize (12). These results show that it is necessary to increase production and make the current production more efficient.

This paper's objective was to assess enterprise-level efficiency (technical, allocative, and economic efficiency) and the determinants of cost efficiency in beekeeping enterprises in Mersin City. There are two approaches to measuring efficiency: data envelopment analysis (DEA) and the stochastic frontier model. Data envelopment analysis (DEA) was preferred in this study since measurement errors were desired to be a minimum in efficiency studies. In the Tobit model, the number of dependent variables is limited compared to linear regression models. In various studies about efficiency analysis in beekeeping, it was seen that Tobit regression was used with analyzing parameters, which were considered to be influential on efficiency $(5,6,8,12,22)$. In this study, the Tobit model was used as only the variables related to the production of beekeeping enterprises were reached.

\section{Materials and Methods}

Research data: The research materials were the survey data obtained from enterprises registered with the Mersin Beekeepers Union. Beekeeping enterprises with a total of 30 or more hives are affiliated with the Union. The stratified random sampling method was used in the formula below to improve the precision of the results obtained from enterprises and ensure sufficient population representation (30).

$$
n=\frac{\Sigma\left(N_{h} S_{h}\right)^{2}}{N^{2} D^{2}+\Sigma N_{h} S_{h}^{2}}, \quad D^{2}=\frac{e^{2}}{t^{2}}
$$

The enterprises were split into three strata, including 30-100 hives classified as small, 101-180 hives classified as medium, and 181 hives and above classified as large enterprises. The total number of beekeeping enterprises was calculated as 81 in the study, with a $10 \%$ sampling error margin and $95 \%$ confidence level $(\mathrm{t}=1.645)$. The number of enterprises surveyed was 41,19 , and 21 in terms of scales, respectively.

Within the study's scope, all data, including the beekeeping enterprises' socio-economic characteristics (age of the beekeeper, size of the household, beekeeping experience, education level, variable and fixed costs in beekeeping activities), were obtained through questionnaires.

DEA and TOBIT models for beekeeping enterprises: The data envelopment analysis (DEA) method was used to analyze the study's beekeeping enterprises' efficiency analysis. There is no need to define a function type for the output component or the cost function using the DEA model. Also, there is no need to specify a distributional form for the inefficiency term (10).

It was suggested that the enterprise's efficiency could be made up of two components: technical efficiency that represents the enterprise's ability to achieve full performance from a defined collection of inputs, and allocative efficiency that reflects the enterprise's ability to use inputs in optimum proportions, provided their respective prices and production technology (13). Using the current technology, an input-oriented technical efficiency calculation can be determined as the linear programming (LP) solution for the $i^{\text {th }}$ enterprise:

$$
\begin{array}{ll}
\operatorname{Min}_{\theta, \lambda} \theta, & \\
\text { Subject to: } & -y_{i}+Y \lambda \geq 0 \\
& \theta_{x_{i}}-X \lambda \geq 0 \\
& \lambda \geq 0,
\end{array}
$$

where $\theta$ is the technical efficiency value between 0 and 1 . The enterprise is on the frontier if the value equals 1. The vector $\lambda$ is a $\mathrm{N} \times 1$ weight vector that determines the $i^{\text {th }}$ enterprise's linear combination. The input-based minimum cost for the $\mathrm{i}^{\text {th }}$ enterprise can be achieved by solving the following LP problem:

$$
\begin{array}{ll}
\operatorname{Min}_{\lambda, \mathrm{xi}^{*}} & w_{i}^{t} x_{i}^{*}, \\
\text { Subject to: } & -y_{i}+Y \lambda \geq 0 \\
& \lambda \geq 0,
\end{array}
$$

where $\mathrm{w}$ is a vector of input prices for the $\mathrm{i}^{\text {th }}$ enterprise; $x_{i}^{*}$ is the input quantity cost-minimizing vector for the $\mathrm{i}^{\text {th }}$ enterprise, determined by the LP, and $\lambda$ is the $\mathrm{N}^{*} 1$ constant vector. The BCC model will be a CCRmodel (Eq. 2) representing a CRS condition without this convexity constraint.

Scale efficiency expresses whether a firm is operating at its optimal size. Based on the CCR and BCCscores, scale efficiency is defined by (11): 


$$
S E=\frac{T E_{C C R}}{T E_{B C C}}
$$

Efficiency measures under CRS and VRS were calculated by using the program DEAP 2.1 (9). The efficiency level was carried out according to Aydin et al. (5), where $\mathrm{TE}=1$ is fully efficient, $0.90 \leq \mathrm{TE} \leq 0.949$ is efficient, $0.90 \leq \mathrm{TE} \leq 0.949$ is less efficient, and TE $\leq$ 0.899 is inefficient.

The Tobit model is used to explain the relationship between the inefficiency scores and variables for demographic and socio-economic characteristics. It defines the Tobit model as follows: (15).

$Y_{i j}=\beta_{0}+\sum_{j=i}^{N} \beta_{i} X_{i}+u_{i}$ if $u_{i}>-\beta_{0}-\sum_{j=i}^{N} \beta_{i} X_{i}$

$$
Y_{i j}=0 \quad \text { if } u_{i} \leq-\beta_{0}-\sum_{j=i}^{N} \beta_{i} X_{i}
$$

$Y_{i}$ is the measure of inefficiency for enterprise $i$; $X_{i}$ is the explanatory variables that influence the enterprises' inefficiencies, $\mathrm{N}$ is the number of explanatory variables; and $\beta$, and $u$ are the model random error term parameters, respectively (23). For the estimation of the Tobit model, the LIMDEP 7.0 statistical and data analysis program was used.

\section{Results}

In the research, one output (honey income), the number of hives, and the costs of feed, drug, fueltransport, honeycomb, jar-tin, temporary labor, accommodation, and repair-maintenance inputs were used to estimate the efficiency of the beekeeping enterprises. Descriptive statistics of the inputs and output are given in Table 1. It was observed that there were high deviations in honey income and production costs according to enterprise scale. The reason for these deviations was to the input and output levels used within each enterprise scale.

The average number of hives was calculated as 77 , 145 , and 312 on the enterprise scale. In terms of honey income, it was determined as 5981.49, 11548.79, and 27971.06 US\$, respectively. One of the most critical components of cost for bees to feed is sugar. According to the enterprise scale, it was determined that the sugar costs were $213.47,521.97$, and 1352.50 US\$, drug costs were 75.21, 186.66, and 686.94 US\$, fuel-transport costs were $302.67,537.62$, and 1186.21 US\$, honeycomb costs were 241.11, 524.03, and 1066.77 US\$, respectively. Beekeepers sell their honey in jar or tin. According to the enterprise scale, the jar-tin costs were determined at $158.13,242.68$, and 399.00 US\$. However, there is often a need for temporary employment, and in terms of enterprise scales, temporary labor costs were determined at 53.76, 210.87, and 465.41 US\$, respectively. The accommodation has essential effects on honey quality. In this context, accommodation costs were determined in terms of enterprise scale at 33.45, 60.65, and 123.94 US\$, respectively. Besides, repair and maintenance costs were $47.73,50.91$, and 132.35 US\$.

The study's findings will increase beekeepers' efficiency and contribute to policymakers, beekeepers' unions, and extension services. According to the inputoriented efficiency analysis results, pure technical efficiency was found at 0.96 for VRS. This value suggests that inefficient beekeeping enterprises could decrease inputs by $4 \%$ without output reduction to ensure efficiency. The pure technical efficiency values were 0.94 , 0.97 , and 0.97 , respectively (Table 2). It can also be said that medium and large enterprises were practically more effective than small enterprises.

\begin{tabular}{|c|c|c|c|c|c|c|}
\hline \multirow[b]{2}{*}{ Output and inputs } & \multicolumn{2}{|c|}{$\underline{\text { Small }}$} & \multicolumn{2}{|c|}{$\underline{\text { Medium }}$} & \multicolumn{2}{|c|}{$\underline{\text { Large }}$} \\
\hline & Mean & $\begin{array}{l}\text { Standard } \\
\text { deviation }\end{array}$ & Mean & $\begin{array}{l}\text { Standard } \\
\text { deviation }\end{array}$ & Mean & $\begin{array}{l}\text { Standard } \\
\text { deviation }\end{array}$ \\
\hline Honey income (US\$) & 5891.49 & 2321.38 & 11548.79 & 2767.18 & 27971.06 & 11090.19 \\
\hline Number of hives (piece) & 77.07 & 20.27 & 144.89 & 17.93 & 312.14 & 108.83 \\
\hline Feed (sugar) costs (US\$) & 213.47 & 88.48 & 521.97 & 116.92 & 1352.50 & 430.47 \\
\hline Drug costs (US\$) & 75.21 & 16.04 & 186.66 & 57.44 & 686.94 & 204.73 \\
\hline Fuel-transport costs (US\$) & 302.67 & 93.10 & 537.62 & 131.69 & 1186.21 & 452.75 \\
\hline Honeycomb costs (US\$) & 241.11 & 208.47 & 524.03 & 567.39 & 1066.77 & 498.44 \\
\hline Jar-tin costs (US\$) & 158.13 & 40.30 & 242.68 & 28.07 & 399.00 & 153.73 \\
\hline Temporary labor costs (US\$) & 53.76 & 51.92 & 210.87 & 119.87 & 465.41 & 294.90 \\
\hline Accommodation costs (US\$) & 33.45 & 20.46 & 60.65 & 24.41 & 123.94 & 78.85 \\
\hline Repair-maintenance costs (US\$) & 47.73 & 13.14 & 50.91 & 10.11 & 132.35 & 44.70 \\
\hline
\end{tabular}

Table 1. Descriptive statistics of the output and inputs by enterprise scale. 
Table 2. Descriptive statistics of technical efficiency scores by enterprise scale.

\begin{tabular}{|c|c|c|c|c|c|c|c|c|c|c|c|c|}
\hline \multirow[b]{2}{*}{$\begin{array}{l}\text { Technical efficiency } \\
\text { scores }\end{array}$} & \multicolumn{3}{|c|}{ Small } & \multicolumn{3}{|c|}{ Medium } & \multicolumn{3}{|c|}{$\underline{\text { Large }}$} & \multicolumn{3}{|c|}{ Average } \\
\hline & CRS & VRS & SE & CRS & VRS & SE & CRS & VRS & SE & CRS & VRS & SE \\
\hline Average & 0.88 & 0.94 & $0.94^{\mathrm{a}}$ & 0.86 & 0.97 & $0.89^{\mathbf{b}}$ & 0.92 & 0.97 & $0.96^{\mathrm{a}}$ & 0.89 & 0.96 & 0.93 \\
\hline Standard deviation & 0.12 & 0.09 & 0.09 & 0.15 & 0.05 & 0.13 & 0.10 & 0.06 & 0.08 & 0.13 & 0.08 & 0.10 \\
\hline Minimum & 0.57 & 0.70 & 0.57 & 0.59 & 0.85 & 0.59 & 0.67 & 0.74 & 0.71 & 0.57 & 0.70 & 0.57 \\
\hline Maximum & 1.00 & 1.00 & 1.00 & 1.00 & 1.00 & 1.00 & 1.00 & 1.00 & 1.00 & 1.00 & 1.00 & 1.00 \\
\hline
\end{tabular}

a,b shows the statistically significant differences between the enterprise scale at a level of $5 \%$.

CRS: constant return to scale; VRS: variable return to scale; SE: Scale efficiency.

Table 3. Classification of technical efficiency scores by enterprise scale.

\begin{tabular}{|c|c|c|c|c|c|c|c|c|}
\hline \multirow[b]{2}{*}{ Technical efficiency scores } & \multicolumn{2}{|c|}{$\underline{\text { Small }}$} & \multicolumn{2}{|c|}{$\underline{\text { Medium }}$} & \multicolumn{2}{|c|}{$\underline{\text { Large }}$} & \multicolumn{2}{|c|}{ Average } \\
\hline & Number & $\%$ & Number & $\%$ & Number & $\%$ & Number & $\%$ \\
\hline Fully efficient $(\mathrm{TE}=1)$ & 26 & 63.41 & 12 & 63.16 & 13 & 61.90 & 51 & 62.96 \\
\hline Efficient $(0.95 \leq \mathrm{TE} \leq 1)$ & 2 & 4.88 & 2 & 10.53 & 3 & 14.29 & 7 & 8.64 \\
\hline Less efficient $(0.90 \leq \mathrm{TE} \leq 0.949)$ & 2 & 4.88 & 3 & 15.79 & 2 & 9.52 & 7 & 8.64 \\
\hline Inefficient $(\mathrm{TE} \leq 0.899)$ & 11 & 26.83 & 2 & 10.53 & 3 & 14.29 & 16 & 19.75 \\
\hline Total & 41 & 100.00 & 19 & 100.00 & 21 & 100.00 & 81 & 100.00 \\
\hline
\end{tabular}

$\mathrm{P}=0.599$

Table 4. Returns to scale by enterprise scale.

\begin{tabular}{|c|c|c|c|c|c|c|c|c|}
\hline \multirow[b]{2}{*}{ Return to scale } & \multicolumn{2}{|c|}{ Small } & \multicolumn{2}{|c|}{ Medium } & \multicolumn{2}{|c|}{$\underline{\text { Large }}$} & \multicolumn{2}{|c|}{ Total } \\
\hline & Number & $\%$ & Number & $\%$ & Number & $\%$ & Number & $\%$ \\
\hline Increasing return to scale & 25 & 60.98 & 11 & 57.9 & 10 & 47.62 & 46 & 56.79 \\
\hline Constant return to scale & 14 & 34.15 & 7 & 36.84 & 10 & 47.62 & 31 & 38.27 \\
\hline Decreasing return to scale & 2 & 4.88 & 1 & 5.26 & 1 & 4.76 & 4 & 4.94 \\
\hline Total & 41 & 100 & 19 & 100 & 21 & 100 & 81 & 100 \\
\hline
\end{tabular}

$\mathrm{P}=0.886$

The average scale efficiency was estimated at 0.93 . This score means that almost all the enterprises in the region were based on technical efficiency. Beekeeping enterprises have been categorized according to technical efficiency in Table 3. Enterprises were determined fully efficient on enterprise scales of $63.41 \%, 63.16 \%$, and $61.90 \%$, respectively (Table 3 ). The chi-square test results revealed that technical efficiency does not differ by enterprise scale, indicating that enterprises use their production resources at the same level $(\mathrm{P}=0.599)$.

On average, $56.79 \%$ of enterprises had an increasing return to scale, $38.27 \%$ had a constant return to scale, and $4.94 \%$ of the beekeeping enterprises had a decreasing return to scale (Table 4). It was determined that the ratio of constant return to scale in large enterprises was higher than in small and medium enterprises. The chi-square test results showed that returns to the scale did not vary by the scale of the enterprise, and this showed that the relationship between the amount of input and output was similar across all enterprise scales $(\mathrm{P}=0.886)$.
Allocative efficiency values varied on a scale between 0.50 and 1.00 and were found to be 0.84 on average (Table 5). This value suggests that many enterprises produced an inaccurate input combination at the current technology level when the current input prices were considered. The enterprises' costs were $16 \%$ more than the input combination with the minimum costs. Allocative efficiency coefficients varied by enterprise scale $(\mathrm{F}=3.547, \mathrm{P}=0.034)$.

Table 5. Descriptive statistics of allocative efficiency scores by enterprise scale.

\begin{tabular}{lcccc} 
& Average & Std. dev. Minimum & Maximum \\
\cline { 2 - 5 } Small & $0.82^{\mathrm{a}}$ & 0.11 & 0.50 & 1.00 \\
Medium & $0.87^{\mathrm{b}}$ & 0.09 & 0.69 & 1.00 \\
Large & $0.88^{\mathrm{b}}$ & 0.07 & 0.76 & 1.00 \\
Average & 0.84 & 0.10 & 0.50 & 1.00
\end{tabular}

a,b Means within these comparisons with different letters are significantly different at $\mathrm{P}<0.05$. 
Based on the enterprises' average, allocative efficiency was determined to be $20.69 \%$ of the enterprises allocating the resources fully efficient, and that value was found to be $7.32 \%, 15.79 \%$, and $14.29 \%$ in terms of scales, respectively (Table 6). The chi-square test findings showed that allocative efficiency varied in enterprise scale, and small enterprises used less technology level and input combination $(\mathrm{P}=0.053)$.

On average, economic efficiency was determined at 0.81 . The value indicated that inefficient beekeeping enterprises had to minimize operating costs by $19 \%$ to become efficient enterprises. According to enterprise scale, economic efficiency values were calculated at 0.77 , 0.84 , and 0.85 , respectively (Table 7 ). Due to the number of hives, it was observed that the large enterprises were more efficient than the small and medium enterprises. There were statistically significant differences in economic efficiency scores between the enterprise scales, and this revealed that small enterprises should provide the optimum combination of inputs by reducing their costs ( $\mathrm{F}=4.3737, \mathrm{P}=0.016)$.

Based on the beekeeping enterprises' average, economic efficiency was calculated to be $7.32 \%$ of small enterprises, $15.79 \%$ of medium enterprises, and $14.29 \%$ of full-efficient. This value was considered $11.11 \%$ on average (Table 8). The chi-square test findings revealed that economic efficiency varied with enterprise scale $(\mathrm{P}=$ 0.070 ), and the rate of efficient enterprises is high in medium-scale enterprises.

The Tobit model was used in the second stage to determine the effect of some socioeconomic factors on economic inefficiency, and the results are shown in Table 9. The Tobit analysis results showed that the gross honey income subsidy rate is negative and statistically significant at all enterprise scales.

Table 6. Classification of allocative efficiency scores by enterprise scale.

\begin{tabular}{|c|c|c|c|c|c|c|c|c|}
\hline \multirow[b]{2}{*}{ Allocative efficiency scores } & \multicolumn{2}{|c|}{ Small } & \multicolumn{2}{|c|}{$\underline{\text { Medium }}$} & \multicolumn{2}{|c|}{$\underline{\text { Large }}$} & \multicolumn{2}{|c|}{ Average } \\
\hline & Number & $\%$ & Number & $\%$ & Number & $\%$ & Number & $\%$ \\
\hline Fully efficient $(\mathrm{TE}=1)$ & 3 & 7.32 & 3 & 15.79 & 3 & 14.29 & 9 & 11.11 \\
\hline Efficient $(0.95 \leq \mathrm{TE} \leq 1)$ & 1 & 2.44 & 3 & 15.79 & 0 & 0.00 & 4 & 4.94 \\
\hline Less efficient $(0.90 \leq \mathrm{TE} \leq 0.949)$ & 4 & 9.76 & 1 & 5.26 & 6 & 28.57 & 11 & 13.58 \\
\hline Inefficient $(\mathrm{TE} \leq 0.899)$ & 33 & 80.49 & 12 & 63.16 & 12 & 57.14 & 57 & 70.37 \\
\hline Total & 41 & 100.00 & 19 & 100.00 & 21 & 100.00 & 81 & 100.00 \\
\hline
\end{tabular}

$\mathrm{P}=0.053$

Table 7. Descriptive statistics of economic efficiency scores by enterprise scale.

\begin{tabular}{|c|c|c|c|c|}
\hline & Average & Std. dev. & Minimum & Maximum \\
\hline Small & $0.77^{\mathrm{a}}$ & 0.13 & 0.50 & 1.00 \\
\hline Medium & $0.84^{\mathrm{b}}$ & 0.12 & 0.66 & 1.00 \\
\hline Large & $0.85^{\mathrm{b}}$ & 0.10 & 0.59 & 1.00 \\
\hline Average & 0.81 & 0.12 & 0.50 & 1.00 \\
\hline
\end{tabular}

${ }^{\mathrm{a}, \mathrm{b}}$ Means within these comparisons with different letters are significantly different at $\mathrm{P}<0.05$.

Table 8. Classification of economic efficiency scores by enterprise scale.

\begin{tabular}{|c|c|c|c|c|c|c|c|c|}
\hline \multirow[b]{2}{*}{ Economic efficiency scores } & \multicolumn{2}{|c|}{$\underline{\text { Small }}$} & \multicolumn{2}{|c|}{$\underline{\text { Medium }}$} & \multicolumn{2}{|c|}{$\underline{\text { Large }}$} & \multicolumn{2}{|c|}{$\underline{\text { Average }}$} \\
\hline & Number & $\%$ & Number & $\%$ & Number & $\%$ & Number & $\%$ \\
\hline Fully efficient $(\mathrm{TE}=1)$ & 3 & 7.32 & 3 & 15.79 & 3 & 14.29 & 9 & 11.11 \\
\hline Efficient $(0.95 \leq \mathrm{TE} \leq 1)$ & 1 & 2.44 & 3 & 15.79 & 0 & 0.00 & 4 & 4.94 \\
\hline Less efficient $(0.90 \leq \mathrm{TE} \leq 0.949)$ & 3 & 7.32 & 1 & 5.26 & 5 & 23.81 & 9 & 11.11 \\
\hline Inefficient $(\mathrm{TE} \leq 0.899)$ & 34 & 82.93 & 12 & 63.16 & 13 & 61.90 & 59 & 72.84 \\
\hline Total & 41 & 100.00 & 19 & 100.00 & 21 & 100.00 & 81 & 100.00 \\
\hline
\end{tabular}

$\mathrm{P}=0.053$ 
Table 9. Tobit analysis results by enterprise scale.

\begin{tabular}{lcccccc}
\hline & \multicolumn{2}{c}{ Small } & \multicolumn{2}{c}{ Medium } & \multicolumn{2}{c}{$\underline{\text { Large }}$} \\
Variables & Coefficient & $\begin{array}{c}\text { Standard } \\
\text { error }\end{array}$ & $\begin{array}{c}\text { Standard } \\
\text { Coefficient }\end{array}$ & $\begin{array}{c}\text { Standard } \\
\text { error }\end{array}$ & $\begin{array}{c}\text { Coefficient } \\
\text { error }\end{array}$ \\
\hline Constant (C) & $0.523^{\mathrm{c}}$ & 0.162 & $2.489^{\mathrm{c}}$ & 0.837 & $1.973^{\mathrm{c}}$ & 0.633 \\
Beekeepers' age (year) & $0.002^{\mathrm{b}}$ & 0.001 & $-0.007^{\mathrm{b}}$ & 0.003 & -0.002 & 0.005 \\
Education period (year) & -0.003 & 0.003 & -0.007 & 0.015 & -0.004 & 0.004 \\
Family size (person) & 0.004 & 0.006 & -0.021 & 0.019 & 0.006 & 0.010 \\
Beekeeping experience (year) & $0.002^{\mathrm{b}}$ & 0.001 & $0.005^{\mathrm{a}}$ & 0.003 & 0.005 & 0.005 \\
Land size (da) & $0.001^{\mathrm{b}}$ & 0.000 & 0.003 & 0.004 & 0.002 & 0.002 \\
Income per hive (US\$) & $0.007^{\mathrm{c}}$ & 0.001 & $0.011^{\mathrm{c}}$ & 0.004 & $0.013^{\mathrm{c}}$ & 0.004 \\
Honey-frame per hive (number) & $0.013^{\mathrm{a}}$ & 0.007 & -0.062 & 0.041 & -0.012 & 0.015 \\
Subsidy rate in gross honey income (\%) & $-0.020^{\mathrm{b}}$ & 0.008 & $-0.182^{\mathrm{a}}$ & 0.099 & $-0.219^{\mathrm{b}}$ & 0.099 \\
Information source (number) & $0.028^{\mathrm{b}}$ & 0.014 & $0.053^{\mathrm{a}}$ & 0.030 & 0.021 & 0.028 \\
Migratory beekeeping (if yes 1; others 0) & $0.064^{\mathrm{c}}$ & 0.021 & -0.024 & 0.067 & 0.057 & 0.064 \\
Off-farm income (if yes 1; others 0) & $-0.044^{\mathrm{a}}$ & 0.023 & 0.045 & 0.072 & $-0.137^{\mathrm{b}}$ & 0.063 \\
Credit usage (if yes 1; others 0) & -0.038 & 0.058 & $-0.178^{\mathrm{b}}$ & 0.076 & $-0.197^{\mathrm{b}}$ & 0.079 \\
\hline
\end{tabular}

a,b,c Values indicate the significance at the $10 \%, 5 \%$ and $1 \%$ level, respectively.

\section{Discussion and Conclusion}

This study revealed that Data Envelopment Analysis (DEA) would be more appropriate to determine the efficiency level of beekeeping enterprises due to diseases and pests on production and changing input and honey prices over the years.

Technical, allocative, and economic efficiency means were estimated at $0.89,0.84$, and 0.81 , respectively. Besides, total technical efficiency was found to be 0.89 and pure technical efficiency was 0.96 on average. In the study on beekeeping conducted in Turkey (8), the average allocative efficiency and economic efficiency of beekeeping in Turkey were found to be 0.75 and 0.62 , respectively. In the study on beekeeping conducted in Turkey (12), the researcher identified the technical efficiency score as 0.84 , and the economic efficiency score as 0.63 . The efficiency scores obtained from the study have higher values than other studies because beekeeping in Mersin City is a more favorable and economic activity for reasons such as climate, flora, and low wintering losses.

The average efficiency scores in beekeeping enterprises were calculated as 0.89 in Tolon KumbunguGhana (1), as 0.55 in Oyo State-Nigeria (2), as 0.89 in Çanakkale-Turkey (5), as 0.97 in Hatay-Turkey (19), as 0.57 in all of Greece (21) and as 0.85 in Adana-Turkey (22). Among the 81 enterprises in the region, $63 \%$ were technically full-efficient, $11 \%$ were allocatively fullefficient, and $11 \%$ were economically full-efficient.

Scale efficiency shows that many enterprises are at an adequate level in their production and that their size is optimal. A study in Çanakkale-Turkey determined technical, allocative, and economics scores of $52.87 \%$, $20.69 \%$, and $17.24 \%$ efficient, respectively (5). A study in Greece determined that technical, allocative, and economics scores were $3.14 \%, 8.36 \%$, and $3.14 \%$ fullefficient, respectively (21).

The definition of pure technical efficiency demonstrates the optimal utilization of inputs on the basis of the return on the variable scale. $56.79 \%$ of beekeeping enterprises increase returns to scale, $38.27 \%$ maintain constant returns to scale, and $4.94 \%$ decrease returns to scale. This situation showed that the production unit had scale efficiency. Other study percentages determined were $77.01 \%, 18.39 \%$, and $4.60 \%$, respectively (5). Since honey production in beekeeping is affected by many factors, especially climatic conditions and input prices, it varies according to years among the enterprises' scale returns.

Experience is significant to maintaining beekeeping effectively. Because experience will enable beekeepers to make reliable and accurate production (29), extension activities should be carried out in a way that will strengthen the communication between beekeepers and publication sources, especially the diagnosis of bee diseases and pests (5).

Subsidies should be included in the factors that affect yield per hive (17), and beekeepers should be aimed at solving the problems in marketing. The study revealed that small-scale enterprises were influenced by social and economic factors, while large-scale enterprises were only economic. Especially for large-scale beekeeping enterprises, providing marketing support instead of subsidies per hive will solve marketing problems. 
If appropriate credit opportunities cannot be provided to the beekeepers, they try to provide the funds they need by working in different jobs or sectors (18). It was noted that the rise in the use of credit harms economic efficiency. In other respects, the subsidy rate in gross honey income was also another variable that adversely impacts economic efficiency.

Agricultural credit is an essential factor in production. Credits for agricultural production need to be restructured for beekeepers who wish to use credit for more productive processing. However, the credit reduces financial restrictions on cash inputs, boosts technical efficiency, and increases resource allocation and profitability (26).

According to the results, subsidies were merely additional revenue, not intended to raise the production amount. For this purpose, new subsidy instruments should be implemented to make more efficient production, improve development technology for beekeepers, and increase rural welfare.

\section{Acknowledgements}

This study was carried out in cooperation with Mersin Beekeepers Union.

\section{Financial Support}

This research received no grant from any funding agency/sector.

\section{Ethical Statement}

This study does not present any ethical concerns.

\section{Conflict of Interest}

The author declared that there is no conflict of interest.

\section{References}

1. Abdul-Malik A, Mohammed A (2012): Technical efficiency of beekeeping farmers in Tolon-Kumbungu district of Northern region of Ghana. J Dev Agric Econ, 4, 304-310.

2. Aburime IL, Omotesho OA, Ibrahim HY (2006): An analysis of technical efficiency of beekeeping farms in Oyo state, Nigeria. Eur J Soc Sci, 4, 1-8.

3. Aksoy A, Ertürk YE, Eyturan, E, et al (2018): Estimation of Honey Production in Beekeeping Enterprises from Eastern Part of Turkey Through Some Data Mining Algorithms. Pakistan J of Zoo, 50, 2200-2207.

4. Al-Ghamdi AA, Adgaba N, Herab AH, et al (2017): Comparative analysis of profitability of honey production using traditional and box hives. Saudi Journal of Biological Sciences, 24, 1075-1080.

5. Aydın B, Aktürk D, Arsoy D (2020): Economic and Efficiency Analysis of Beekeeping Activity in Turkey: Case of Çanakkale Province. Veterinary Journal of Ankara University, 67, 23-32.

6. Barlovic N, Kezic J, Benedic ON, et al (2009): Economic efficiency of beekeeping in Croatia. Agriculturae Conspectus Scientificus, 74, 51-54.

7. Borum AE (2017): A study of beekeeping survey in Southern Marmara region of Turkey. U Bee J, 17, 24-34.

8. Ceyhan V, Canan S, Yıldırım Ç, et al (2017): Economic structure and services efficiency of Turkish Beekeepers' Association. Eur J Sustain Dev, 6, 53-64.

9. Coelli TJ (1996): A guide to DEAP Version 2.1: a data envelopment analysis (Computer) program, CEPA Working Paper, No. 8/96, ISBN 186389 4969, Department of Econometrics, University of New England, p. 49.

10. Coelli TJ, Rao DSP, Battese GE (1998): An Introduction to Efficiency and Productivity Analysis. Kluwer Academic Publishers, Boston.

11. Cooper WW, Seiford LM, Tone K (2006): Introduction to DEA and its uses with DEA-Solver software and references. New York: Springer.

12. Emir M (2015): Exploring the socio-economic structure of beekeepers and their production efficiency in Turkey. $\mathrm{PhD}$ Thesis. Ondokuz Mayis University Department of Agricultural Economics, Samsun.

13. Farrell MJ (1957): The Measurement of Productive Efficiency. Journal of the Royal Statistical Society, 120, 253-281.

14. Fıratlı Ç, Karacaoğlu M, Gençer H, et al (2010): Structural analysis of beekeeping Turkey. In Proceedings of Turkey Agricultural Engineering VII. Technical Congress (pp. 707-717). Ankara, Turkey.

15. Gujarati DN (1999): Basic Econometrics. $2^{\text {nd }}$ Edition, Mc Graw Hill. Literatür Publishing, İstanbul.

16. Güler A, Demir M (2005): Beekeeping potential in Turkey. Bee World, 86, 114-118.

17. Gürer B, Akyol E (2018): An empirical analysis of technical efficiency determinants in beekeeping farms: evidence and policy implications from Niğde Province, Turkey. JAEID, 112, 343-359.

18. Karadas K, Kadirhanogullari IH (2017): Predicting honey production using data mining and artificial neural network algorithms in apiculture. Pakistan J Zool, 49, 16111619.

19. Kaya U, Gürcan S (2021): An evaluation of the efficiency of beekeeping enterprises in Hatay province with data envelopment analysis. Ankara Univ Vet Fak Derg, Available at http://vetjournal.ankara.edu.tr/tr/pub/issue/ 48904/754619 (Accessed January 14, 2021).

20. Kosoğlu M, Yucel B, Ozsoy N, et al (2017): Effects of Queen Bee on Colony Development and Management Economy in Turkish Beekeeping. Turkish Journal of Agricultural Economics, 23, 55-60.

21. Makri P, Papanagiotou P, Papanagiotou E (2015): Efficiency and economic analysis of Greek beekeeping farms. Bulg J Agric Sci, 21, 479-484.

22. Ören N, Alemdar T, Parlakay O, et al (2010): Economic Analysis of Beekeeping Activity in Adana Province. Agricultural Economics Research Institute Edition No: 78, Ankara.

23. Ramanathan R (1998): Introductory Econometrics with Applications. The Dryden Press, USA. 
24. Sancak K, Zan Sancak A, Aygören E (2013): Beekeeping in the World and Turkey. Arıcılık Araştırma Dergisi, 5, 713.

25. Siralı R (2002): General Beekeeping Structure of Turkey. U Bee J, 2, 30-39.

26. Sial MH, Awan MS, Waqas M (2011): Role of Institutional Credit on Agricultural Production: A Time Series Analysis of Pakistan. International Journal of Economics and Finance, 3, 126-132.

27. Tamali H, Özkırım A (2019): Beekeeping Activities in Turkey and Algeria. Mellifera, 19, 30-40.
28. TURKSTAT (2020): Turkey Statistical Institute, Statistical Indicators. Available at https://biruni.tuik.gov.tr/medas/?kn $=92$ \&locale $=\operatorname{tr}$ (Accessed December 22, 2020).

29. Vanengelsdorp T, Tarpy DR, Baylis K, et al (2012): The bee informed partnership: using beekeeper's real-world experience to solve beekeepers' real-world problems. American Entomologist, 58, 116-118.

30. Yamane T (1967): Elementary sampling theory. Englewood Cliffs, N.J.: Prentice Hall, Inc. 